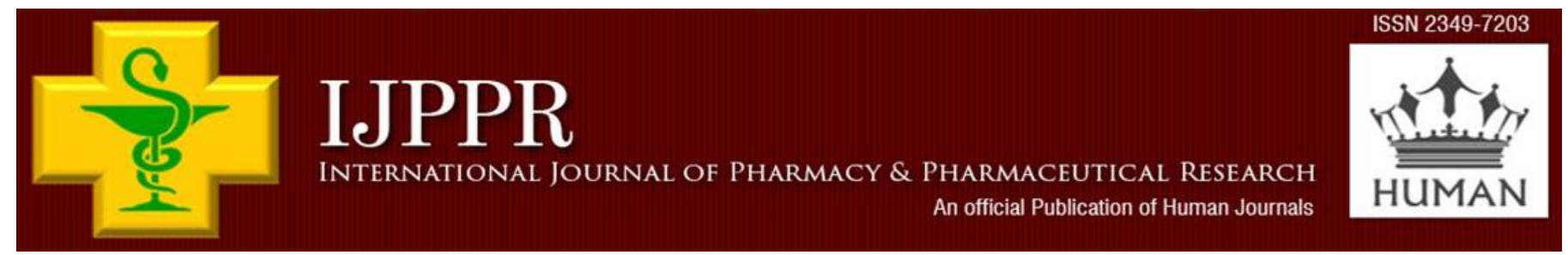

Human Journals

Review Article

August 2021 Vol.:22, Issue:1

(c) All rights are reserved by Dheeraj Dubey et al.

\title{
A Comprehensive Review on Anti-Inflammatory Activity of The Traditional Plants Plumbago zeylanica(Chitra)
}

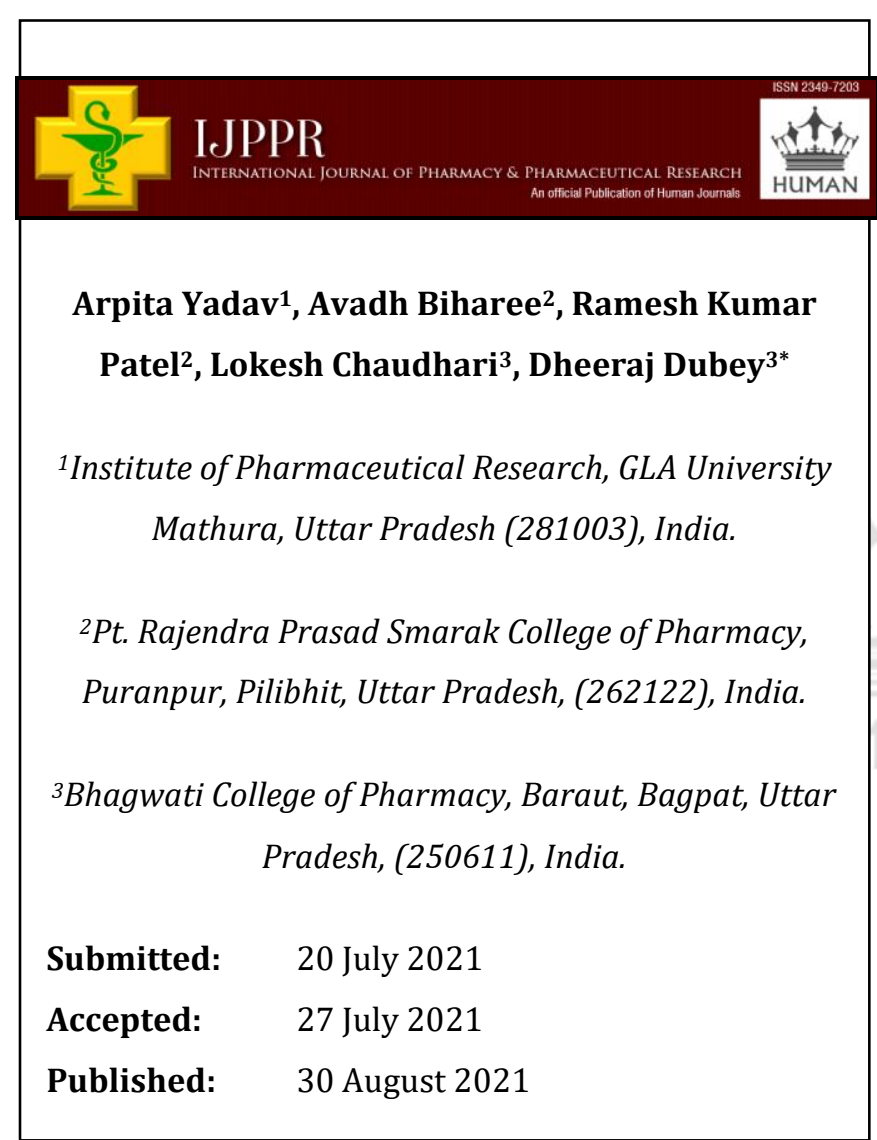

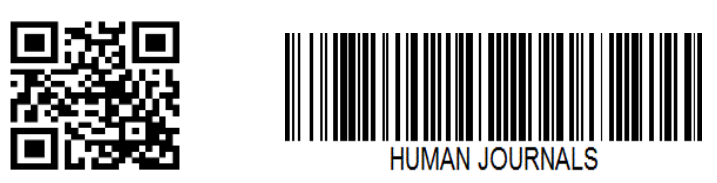

www.ijppr.humanjournals.com
Keywords: Plumbago zeylanica, chitra, chemical composition, anti-inflammatory

\section{ABSTRACT}

Medicinal plants have long been utilised as a source of medicine and are in high demand throughout the world. They've been around for a long time, and they've been utilised to cure and prevent ailments. Plumbago zeylanica is a medicinal plant that is frequently utilised for its medicinal properties. It contains several bioactive compounds like napthoquinones, flavonoids, alkaloids, glycosides, steroids, tri-terpenoids, tannins, fixed oils, fats, proteins, etc. among all plumbagin is most important bioactive compounds. It possesses wide range of pharmaceutical activities such as anti-inflammatory, antimicrobial, anti-cancer, anti-ulcer, antidiabetic etc. Several investigations on its pharmacological activity have been conducted. The goal of this review is to provide a comprehensive understanding of P. zeylanica's chemical composition and pharmacological action. 


\section{INTRODUCTION}

Inflammation is a temporary biological reaction of tissues to adverse stimuli such as injury, exogenous and endogenous antigens, with the goal of clearing or eliminating the stimulus and repairing the wounded tissue, eventually leading to regeneration and return to equilibrium. Although inflammation is a beneficial defense mechanism for the body, it has long been recognized as the root cause of a variety of diseases, including diabetes, allergies, atherosclerosis, obesity, cancer, and pain. Furthermore, inflammatory dysregulation that leads to chronic diseases contributes to rising health-care costs [1, 2]. The mode of action for inflammation is similar for all and having specific symptoms of inflammatory action that enhances the flow of blood and increased the cellular metabolism, vasodilation, soluble mediators releases, fluids extravasation and influx by cellular means instead of triggering cause [3]. When an inflammatory agent is present, cell membranes activate phospholipase A2, give the deleveriance of arachidonic acid and other inflammation mediators like cytokine, histamine, prostaglandin, and leukotrienes, which increase vascular permeability and allow leukocytes to migrate to the site of inflammation that enhances the permeability of vascular and allow leukocytes to migrate to the site of inflammation $[4,5]$. At the initial stage of inflammation, the leukotrienes, prostaglandins, and histamine binding occur to the respective receptors on the endothelial cells, resulting the vasodilation and contraction of the endothelial cells and enhancement in its permeability of blood vessels. On endothelial cells that line the venules, histamine causes an increase in P-selectin (a cell adhesion protein) and platelet-activating factor (PAF). The results of P-selection and PAF bind is the occurrence of extravasion and binding occur to the leukocyte following its migration to the chemotactic chemicals like complement protein $\mathrm{C} 5 \mathrm{a}$ and leukotriene B4 that produces at the injury location of the cells. On other there is activation of macrophages and endothelial cells which releases the inflammation in cytokines like TNF and IL-1, results binding of receptors on the endothelial cells maintain the inflammation responses by up regulation of the adhesion molecules E-selecting and also maintains the P-selectin expression. The leukocyte attaches with E-selecting and moving via basement membrane for searching the chemokine's that are result of infection cells like IL-8 and monocyte chemotactic protein-1 (MCP-1) $[1,4,5]$. The reason inflammation can be various and if there is presence of inflammation in the body the body reacts at high level of biomarkers. The immune reaction when triggered by the physical parameters inflammation occurs in the body. There is not necessary that if inflammation occurs there is any type of infection in the body but if there is infection can cause the 
inflammation. Treatment for inflammation depends upon the severity and type of inflammation as there is number of anti-inflammatory chemicals that helps in treating the disorders related to the inflammation. Sometimes if not treated in a proper manner can become life threating as some infection entered into the blood and cause sepsis. Inflammation is taken as the protective response in the body for elimination of foreign stimuli. Number of herbal supplements helps in managing the inflammation including numerous medicinal plants and their constituents used traditionally all over the world to cure disorders of inflammation related to lungs and skin. Natural anti-inflammatory agents are some essential oils and their isolated constituents like monoterpenes that helps in searching the bioactive natural compounds against inflammation and their reported actions are mentioned below. The testing for confirmation in the results of anti-inflammatory agents mostly completed on the rates by keeping all the ethics in consideration and without harming them other models used for testing are carrageenan, formalin, and arachidonic acid for producing paw edema and also the in vivo and vitro protocols including the essential oils or monoterpenes [6]. The term pharmacognosy has been obtained from the Greek words pharmacon, which means drug or medicine, and gnosis, which means knowledge. In 1895, C.A. Seydler coined the word "analectapharmacognosia" in his dissertation "Analectapharmacognosia." Herbal remedies are effective in treating a variety of ailments and have been used in health care for decades as a traditional medicinal system for maintaining and healing human health $[7,8]$.

In Ayurveda and Siddha, it was estimated that roughly around 1500 and 1200 species respectively are being used in the preparation of drugs for treating number of disorders. This Indian traditional medicine system used for decades and has proof of numerous successful outcomes and in practice for a long time but there is a lack of standardization related to the identification of crude drugs, their preparation procedures, and the quality of the final product. Recently pharmacognostical studies has been carried out on large number of plants viz. Astercantha longifolia, Andrographis paniculata [9], Butea monosperma [10], Catheranthus roseus [11], Pedalium mures [12], Ageratum conyzoids [13], Barleria prionitis, Phyllanthus spp. [14], Pogostemon [15], Salvia [16], Mentha spp. [17], Thymus spp. [18], Hibiscus sabdaritta [19], Rosmarinus spp. [20], Ocimum spp.[19, 21], Vasakhanda kushmandaka [22], Adhatoda vasica [23-30]. 


\section{MORPHOLOGICAL DESCRIPTION}

The Plumbago zeylanica is commonly known as Ceylon leadwort, Chita, Chitra and Chitramoolam. P. zeylanica Linn (Plumbaginaceae) is perennial, sub-scandant shrub one of the common plants used in Indian traditional system of medicine Figure 1. The family Plumbaginaceae consists of 10 genera and 280 species. The genus Plumbago includes 3 species, namely Plumbago indica (P. rosea) Plumbago capensis and Plumbago zeylanica, which are distributed in several parts of India. Among these species; P. zeylanica grows all districts of plains in Andhra Pradesh, Karnataka, Maharashtra etc. common, wild or in cultivation due to its more therapeutic uses and the flowering tops of the P. zeylanica is showing in Figure 2 [31].

Botanical classification of $P$. zeylanica

\begin{tabular}{|l|l|}
\hline Kingdom & Plantae \\
\hline Order & Caryophyllales \\
\hline Family & Plumbaginaceae \\
\hline Genus & Plumbago \\
\hline Species & P. zeylanica \\
\hline
\end{tabular}

Figure 1. Botanical classification of P. zeylanica

The root is used as laxative, expectorant, astringent, abortifacient, and in dysentery[32]. Tincture of root bark is used as antiperiodic. The leaves are used as aphrodisiac and in scabies. Its roots are used in traditional system of medicine to cure various ailments like body pain, headache, fever and inflammation[33]. P. zeylanica roots were reported to possess antioxidant, hypolipidemic, anti atherosclerotic, central nervous system stimulant and antifertility properties $[34,35]$. 


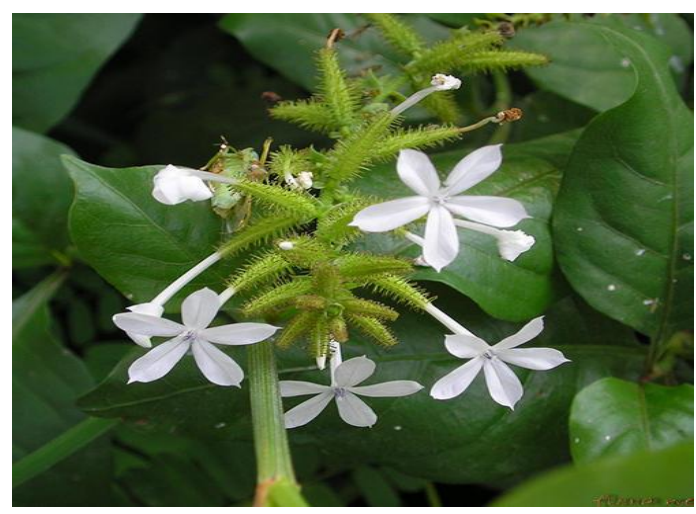

Figure 2. Fresh flowering top of P. zeylanica

P. zeylanica is a subscadent, pretty perennial shrub with semi woody stems and numerous branches. Its leaves are simply alternate, ovate, narrowed into petiole, oblong-lanceolate and acute. Its flowers are borne in spikes, whereas the rachis of the spike is pubescent or glandular. The Corolla white tube is long and slender. The roots are cylindrical and are irregularly bent having transverse shallow fissures at bents. Its fruits are oblong and its capsules are enclosed by persistent viscid calyx [14, 32].

\section{PHYTOCHEMICAL PROFILE}

Earlier chemical examination of this plant revealed that the root contains plumbagin, 3chloroplumbagin, 2,3- biplumbagin, 6,6- biplumbagin, zeylinone, isozeylinone, chitranone (3, 3'-biplumbagin), droserone, plumbagic acid, plumbazeylanone, glucose, fructose, enzymes as protease and invertase. The leaves and stem contain little or no plumbagin. The aerial parts contain naphthoquinones, sitosterol, lupeol, lupenylacetate, hentriacontane, and amino acids. Plant contains naphthaquinones, plumbagin, chloroplumbagin, droserone, zeylinone, isozeylinone, plumbagic acid, plumba-zeylanone, naphthelenone, isonaphthelenone, isoshinanolone [14, 36]. Aspartic acid, tryptophan, tyrosine, threonine, alanine, histidine, glycine, methionine, hydroxyproline, were isolated from the aerial parts [37].

\section{PHARMACOLOGICAL PROFILE \& ETHNOPHARMACOLOGICAL USES}

All parts of the plant have been used in Ayurvedic and Unani medicine to treat anaemia, rheumatoid discomfort, sprains, dysmenorrhea, carbuncles, fleabites, leprosy, internal injuries of the extremities and intestinal parasite eradication. Some of the potential healing properties of the plant's roots and ingredients are antiatherogenic, cardiotonic, neuroprotective, and central nervous system stimulating [38]. Several investigations have shown that P. zeylanica 
possesses antidiarrheal, antiallergic, insecticidal, hepatoprotective, hypolipidaemic, antiinflammatory and antitumour activity, as well as being antibacterial, antifungal and antibiotic, and can be taken orally to treat urinary tract infections [39]. Various disorders such as dyspepsia, piles, diarrhoea, and skin diseases are treated with the plant in Indian medicine. It is also deployed in a number of ayurvedic formulations. As a digestive aid, it is supposed to promote appetite and digestion. According to research, plumbago roots exhibit immunosuppressive and anticancer properties [40].

\section{ANTI-INFLAMATORY ACTIVITY}

This plant has been studied extensively for its anti-cancer, anti-leishmanial, and antiplasmodial properties, as well as for its anti-inflammatory and hypoglycemic, antiatherosclerotic, antiallergic, central nervous system stimulatory, cytotoxic and insecticidal properties, among others. In this review we are emphasizing only on antiinflammatory activity of the $P$. zeylanica Li et al. Studied proapoptotic and growth-inhibitory effects of Plumbagin on human gastric cancer cells via suppression of signal transducer and activator of transcription 3 and protein kinase B. Result showed that plumbagin suppressed the BAX, BCL-2, pro-caspase-3 expression and cleaved caspase-3 in gastric cancer cells. Plumbagin inhibits the apoptosis in human gastric cancer cells that may be due to its ability to suppress the STAT3 and Akt phosphorylation [41]. Shweta et al,. studied antimicrobial activity of leaves extract of Plumbago zeylanica plant against known drugs. Effect of crude extract of $P$. zeylanica leaves against E.coli, Bacillus cereus, Staphylococcus aureus, and Candida was observed and it was found that they exhibits inhibition zones which indicates the potential anti- microbial activity of P. zeylanica [42]. Honnegowda et al,. Reported the evidence of oxidative stress in the pathogenesis of non-healing ulcers. As the wound healing mainly depends on a low level of oxidant so the antioxidant nature of the plant extract obtained from $P$. zeylanica helps in controlling the wound oxidative stress thus accelerating wound healing [43]. Venkatadri et al,. reported anti-cancer activities of $P$. zeylanica extracts against MCF-7 and HT-29 cell lines. Result showed that methanolic extract of $P$. zeylanica were used against MCF-7 and HT-29 and it results in moderate anti-cancer activity and the inhibitory property compared with the standard tamoxifen for MCF-7 and 5-fluoro Uracil for HT-29. 50.23\% of MCF-7 cell death and $25.17 \%$ of HT-29 cell inhibition were observed [44]. Jyothi et al,. investigated the wound healing activity of ethanolic root extract of $P$. zeylanica in wistar rats and found that the activity is due to the presence of phytochemicals such as alkaloids, terpenoids, flavonoids, saponins etc. and these compounds are responsible for the wound 
healing activity of the plant [45]. Falang et al,. revealed the anti-ulcer activity of $P$. zeylanica root extract (aqueous) on aspirin and indomethacin induced acute gastric ulcer in albino rats. By determining and comparing the ulcer index, score and percentage protection of extract with that of the control and negative experiment groups, it was found that $50 \mathrm{ml} / \mathrm{kg}$ and $100 \mathrm{ml} / \mathrm{kg}$ showed significant dose-dependent inhibition in case of aspirin and $50 \mathrm{mg} / \mathrm{kg}$ and $100 \mathrm{mg} / \mathrm{kg}$ in case of indomethacin. Also, oral acute toxicity testing showed that LD50 was greater than $5000 \mathrm{mg} / \mathrm{kg}$ which indicates the wide margin of root extract safety [46]. Sunil et al,. evaluated the antidiabetic effects of plumbagin isolated from $P$. zeylanica root and its effect on GLUT4 translocation in STZ-induced diabetic rats [47]. Patil et al,. Tested extracts of $P$. zeylanica and $C$. nocturnum for larvicidal activity against second, third, and fourth instar larvae of Aedes aegypti. The LC (50) values of all the extracts in different solvents of both the plants were less than $50 \mathrm{ppm}$ (15.40 to $38.50 \mathrm{ppm}$ ) against all tested larval instars. Plant extracts also affected the life cycle of A. aegypti by inhibition of pupal development and adult emergence with increasing concentrations [48]. Dang et al,. analysed three medicinal plants namely Phyllanthus emblica, P. zeylanica and Cyperus rotundus on two models of acute inflammation and result showed that $P$. zeylanica reduce the oedema while the combination of $P$. emblica compared to aspirin[49]. Kodati et al,. investigated wound healing activity of Plumbago zeylanica in rat. Significant wound healing activity of methanolic root extract of Plumbago zeylanica was observed [50]. Zarmough et al,. showed that In streptozotocin-treated diabetic rats, oral administration of ethanolic root extract of $P$. zeylanica (100 mg, $200 \mathrm{mg} / \mathrm{kg} / \mathrm{p} . \mathrm{o})$ and tolbutamide (250 mg/kg/p.o) boosted hexokinase activity and lowered glucose-6-phosphatase activity $(\mathrm{P}<0.001)$ [51]. Vishnukanta \& Rana evaluated in female wistar rats, the hydroalcoholic extract of Plumbago zeylanica leaves has antifertility action. Because of anti-estrogenic activity, which antagonises estrogen's effect and produces structural and functional alterations in the uterus, Plumbago zeylanica leaves demonstrated highly powerful $(95.167 \%)$ anti-implantation activity. The antiestrogenic action is also supported by a decrease in glycogen content, endometrial width and thickness, myometrium, uterine lumen with fewer pits and folds, uterine gland number and size, vaginal opening, and cornification [52]. Sheeja et al,. studied using in vivo experimental models, researchers investigated the anti-inflammatory properties of several $P$. zeylanica leaf extracts. When compared to the control group, the acetone extract significantly ( $\mathrm{p}$ 0.01) decreased inflammation in the carrageenan-induced rats [53]. Mittal et al,. Reported the effect of $P$. zeylanica roots on scopolamine-induced amnesia in rats in terms of learning and memory In mice, a chloroform extract of the plant at a concentration of $200 \mathrm{mg} / \mathrm{kg}$ had a potential 


\section{www.ijppr.humanjournals.com}

memory-enhancing effect. Scopolamine (0.4 mg/kg i.p.)-induced amnesia was significantly restored by the extract [33]. Nile \& Khobragade determined Spectral data for the novel flavonoid 2-(2,4-Dihydroxyphenyl)-3,6,8 trihydroxy chromen-4-one from P. zeylanica roots. Free radical scavenging and superoxide radical scavenging methods were used to investigate antioxidant activity. The antioxidant activity measured by DPPH was $96 \mathrm{~g} / \mathrm{ml}$ and by NBT was $4.6 \mathrm{~g} / \mathrm{ml}$, both of which were higher than the reference (quercetin), which was $45 \mathrm{~g} / \mathrm{ml}$ by DPPH and $10 \mathrm{~g} / \mathrm{ml}$ by NBT assay [54]. Chauhan et al,. In his study carried out Plumbago zeylanica was subjected to preliminary phytochemical screening and anticancer testing in an animal model of Ehrlich Ascites Carcinoma. Because of the greater quantity of terpenoids and flavonoids in the ethanolic extract of Plumbago zeylanica, they discovered that it has substantial anticancer potential and also reduces elevated levels of lipid peroxidation [55]. Maniafu et al,. reported Extracts from three Plumbago species have larvicidal action against A. gambiae. Hexane $(\mathrm{LC} 50=6.4 \mathrm{~g} / \mathrm{mL})$ and chloroform $(\mathrm{LC} 50=6.7 \mathrm{~g} / \mathrm{mL})$ extracts were shown to have the strongest larvicidal activity against Anopheles gambiae [56]. Edwin et al,. investigated that the acetone and ethanol extracts of $P$. zeylanica were the most effective at interrupting the estrous cycle, resulting in a prolonged diestrous stage of the cycle and a transient suppression of ovulation. P. zeylanica also serves as a family planning and antiimplantation agent in humans, obstructing progesterone production or usage [57]. Checker et $a l$,. studied Plumbagin's anti-inflammatory properties are due to its inhibition of NF kappa B activation in lymphocytes. $P$. zeylanica inhibited NF-kappa B activation in tumour cells and reduced mortality in mice with Graft Versus Host Disease [58]. Vishnukanta \& Rana evaluated Plumbago zeylanica leaf hydroalcoholic extract for central nervous system activity The extract had considerable CNS depressive effects as well as muscle relaxant effects, according to the researchers. It also had anxiolytic properties [52]. Kotecha \& Rao et al,. Investigated the effect of $500 \mathrm{mg}$ of Plumbago zeylanica and $1 \mathrm{gm}$ of haridra powder in capsules given four times a day for 45 days to obese patients on a low-calorie diet. When compared to haridra, the results showed that $P$. zeylanica is significantly significant in the weight loss of the patient [59]. Sandur et al,. Showed that Plumbagin, a compound produced from $P$. zeylanica, inhibits cell growth, carcinogenesis, and radio resistance. The activation of the transcription factor NF-kappa B activation pathway should govern all of these events. Plumbagin prevents TNF, other carcinogens, and inflammatory triggers like phorbol myristate acetate from activating NF-kappa B [60]. Dai et al,. Investigated ethanolic extracts (70\%) from $P$. zeylanica stems cause allergic responses. The extracts $(500,1000 \mathrm{mg} / \mathrm{kg}$ orally) reduced homologous passive cutaneous anaphylaxis and skin reactions generated by 
histamine or serotonin in rats and prevented dose-dependently systemic anaphylactic shocks generated by compound $48 / 80$ in mice. At a dose of $1000 \mathrm{mg} / \mathrm{kg}$, significant variations were detected [61]. D'Souza et al,. Inclusion To improve efficacy and solubility, a combination of plumbagin and hydroxyl propyl $\beta$-Cyclodextrin (HPßCD) was created. The antifertility action of the combination was tested after it was entrapped in the aqueous layer of niosomes. When compared to the control and niosomes with lipid layer entrapment, the complex's niosomes showed promising anti-fertility action when given intraperitoneally at a dose of $5 \mathrm{mg} / \mathrm{kg}$ [62]. Alpana et $a l$,. also revealed When hyperlipidemic rabbits were given $500 \mathrm{mg} / \mathrm{kg}$ ethanolic extract of $P$. zeylanica, blood cholesterol, LDL cholesterol, and triglycerides all decreased significantly [63]. Rout et al,. evaluated When taken orally or administered to the ostium uteri, the roots of Plumbago zeylanica have been known to be a strong poison that causes abortion [64]. Premakumari et al,. reported In albino rats, plumbagin has strong antiimplantation and abortifacient activity without causing teratogenic effects at dosages of 1mg/100g [65]. Arunachalam et al,. revealed the Chitrak plant (Plumbago zeylanica) was discovered to have an anti-inflammatory effect in carrageenin-induced raw paw oedema in rats. Four groups were used in the study, two of which were given $300 \mathrm{mg} / \mathrm{kg}$ and the other two were given $500 \mathrm{mg} / \mathrm{kg}$, confirming the acute inflammation inhibition of 31.03 percent and $60.30 \%$, respectively [40].

\section{CONCLUSION}

The numerous studies such as morphology, pharmacognostic, phytochemical and physiochemical review of the Plumbago zeylanica were done by literature review concluded that plants of Plumbago zeylanica exhibited anti-inflammatory activities. This plant has been utilised in Ayurvedic medicine for thousands of years to improve longevity and vigour. In herbal formulations, it's the most important medicinal plant. As a multifunctional medicinal agent, it contains a variety of active chemicals, including plumbazin, chitranone, zeylanone, and several valuable naphthaquinone components. $P$. zeylanica and its botanical ingredients have been studied as antiinflammatory agents in this study. This review provides the exhaustive evidence of anti-inflammatory activity of $P$. zeylanica. More studies need to be done for finding of pharmacological and chemical characters finding to know the accurate mechanism of action of the formulation for isolating the active principles responsible for this type of actions. 


\section{Conflict of interest}

Authors declare no conflict of interest.

\section{Acknowledgements}

Corresponding author would like to acknowledge the Director and Head of the Department of Bhagwati College of Pharmacy, Baraut, Bagpat, Uttar Pradesh, (250611), India. One of the authors Arpita Yadav would like to acknowledge her M. Pharm. Supervisor Dr. Jeetendra Kumar Gupta (Institute of Pharmaceutical Research, GLA University Mathura, Uttar Pradesh (281003), India) for his continuous support and motivation to complete this study in an organised way.

Ethics approval and consent to participate: Not applicable.

Human and animal rights: Not applicable.

Consent for publication: Not applicable.

Code availability: Not applicable.

Author contribution: All authors have contributed equally.

\section{REFERENCES:}

1. Mizuno Y, Jacob RF, Mason RP (2011) Inflammation and the development of atherosclerosis: effects of lipid-lowering therapy. Journal of atherosclerosis and thrombosis.1103160359-1103160359.

2. Su S, Wang T, Duan J-A, Zhou W, Hua Y-Q, Tang Y-P, Yu L, Qian D-W (2011) Anti-inflammatory and analgesic activity of different extracts of Commiphora myrrha. Journal of ethnopharmacology. 134(2):251-258.

3. Ferrero-Miliani L, Nielsen O, Andersen P, Girardin S (2007) Chronic inflammation: importance of NOD2 and NALP3 in interleukin-1 $\beta$ generation. Clinical \& Experimental Immunology. 147(2):227-235.

4. Dassoler M, Schwanz M, Busseto F, Moreira E, Gutierrez L (2004) Perfil fitoquímico e ensaio farmacológico de Averrhoa carambola L.(Oxalidaceae). J Brasileiro Fitomedicina. 2:4-8.

5. Falcão HdS, Lima IO, Santos VLd, Dantas HdF, Diniz MdF, Barbosa-Filho JM, Batista LM (2005) Review of the plants with anti-inflammatory activity studied in Brazil. Revista Brasileira de Farmacognosia. 15(4):381391.

6. Vezzani A, French J, Bartfai T, Baram TZ (2011) The role of inflammation in epilepsy. Nature reviews neurology. 7(1):31-40.

7. Kunwar RM, Adhikari N (2005) Ethnomedicine of Dolpa district, Nepal: the plants, their vernacular names and uses. Lyonia. 8(1):43-49.

8. Nweze EI, Eze EE (2009) Justification for the use of Ocimum gratissimum L in herbal medicine and its interaction with disc antibiotics. BMC complementary and alternative medicine. 9(1):1-6.

9. Trivedi NP, Rawal U (2001) Hepatoprotective and antioxidant property of Andrographis paniculata (Nees) in $\mathrm{BHC}$ induced liver damage in mice.

10. Srivastava M, Srivastava SK, Khatoon S, Rawat A, Mehrotra S (2002) Pharmacognostical evaluation of seed of Butea monosperma Kuntze. Natural Product Sciences. 8(3):83-89. 
11. Verpoorte R (2004) The Catharanthus alkaloids: pharmacognosy and biotechnology. Curr Med Chem. $11: 1241$.

12. Shukla V, Khanuja S (2004) Chemical, pharmacological and botanical studies on Pedalium murex.

13. Moura A, Silva E, Fraga M, Wanderley A, Afiatpour P, Maia M (2005) Antiinflammatory and chronic toxicity study of the leaves of Ageratum conyzoides L. in rats. Phytomedicine. 12(1-2):138-142.

14. Chen Z-F, Tan M-X, Liu Y-C, Peng Y, Wang H-H, Liu H-G, Liang H (2011) Synthesis, characterization and preliminary cytotoxicity evaluation of five Lanthanide (III)-Plumbagin complexes. Journal of Inorganic Biochemistry. 105(3):426-434.

15. Deguerry F, Pastore L, Wu S, Clark A, Chappell J, Schalk M (2006) The diverse sesquiterpene profile of patchouli, Pogostemon cablin, is correlated with a limited number of sesquiterpene synthases. Archives of biochemistry and biophysics. 454(2):123-136.

16. Kamatou GP, Van Zyl R, Van Vuuren S, Figueiredo A, Barroso J, Pedro L, Viljoen AM (2008) Seasonal variation in essential oil composition, oil toxicity and the biological activity of solvent extracts of three South African Salvia species. South African Journal of Botany. 74(2):230-237.

17. Gulluce M, Sahin F, Sokmen M, Ozer H, Daferera D, Sokmen A, Polissiou M, Adiguzel A, Ozkan H (2007) Antimicrobial and antioxidant properties of the essential oils and methanol extract from Mentha longifolia L. ssp. longifolia. Food chemistry. 103(4):1449-1456.

18. Rota MC, Herrera A, Martínez RM, Sotomayor JA, Jordán MJ (2008) Antimicrobial activity and chemical composition of Thymus vulgaris, Thymus zygis and Thymus hyemalis essential oils. Food control. 19(7):681687.

19. Humadi SS, Istudor V (2008) Quantitative analysis of bio-active compound in Hibiscus sabdariffa L. extracts. Note I Quantitative analysis of flavonoids. Farmacia. 6:669-707.

20. Bousbia N, Vian MA, Ferhat MA, Petitcolas E, Meklati BY, Chemat F (2009) Comparison of two isolation methods for essential oil from rosemary leaves: Hydrodistillation and microwave hydrodiffusion and gravity. Food chemistry. 114(1):355-362.

21. Hussain AI, Anwar F, Shahid M, Ashraf M, Przybylski R (2010) Chemical composition, and antioxidant and antimicrobial activities of essential oil of spearmint (Mentha spicata L.) from Pakistan. Journal of Essential Oil Research. 22(1):78-84.

22. Kuntal G, Baghel M, Harish C (2012) A preliminary pharmacognostical and physicochemical assay of Vasakhanda Kushmandaka granules. International Journal of Research in Ayurveda and Pharmacy (IJRAP). 3(1):71-76.

23. Badruzzaman Siddiqui M, Husain W (1993) Traditional treatment of gonorrhoea through herbal drugs in the province of central Uttar Pradesh, India. Fitoterapia. 64:399-399.

24. Chowdhury MSH, Koike M, Muhammed N, Halim MA, Saha N, Kobayashi H (2009) Use of plants in healthcare: a traditional ethno-medicinal practice in rural areas of southeastern Bangladesh. International Journal of Biodiversity Science \& Management. 5(1):41-51.

25. Dhankhar S, Kaur R, Ruhil S, Balhara M, Dhankhar S, Chhillar A (2011) A review on Justicia adhatoda: a potential source of natural medicine. African journal of plant science. 5(11):620-627.

26. Gangwar AK, Ghosh AK (2014) Medicinal uses and pharmacological activity of Adhatoda vasica. Int J Herb Med. 2(1):88-91.

27. Kumar M, Dandapat S, Kumar A, Sinha M (2013) Anti-typhoid activity of Adhatoda vasica and Vitex negundo. Persian Gulf crop protection. 2(3):64-75.

28. Paliwa J, Dwivedi A, Singh S, Gutpa R (2000) Pharmacokinetics and in-situ absorption studies of a new anti-allergic compound 73/602 in rats. International journal of pharmaceutics. 197(1-2):213-220.

29. Rashmi P, John R, Mathew L (2012) Isolation and characterization of vasicine from in vitro cultures of Justicia adhatoda. Int J Pharm and Bio Sci. 3:58-64.

30. Srivastava S, Verma RK, Gupta MM, Singh SC, Kumar S (2001) HPLC determination of vasicine and vasicinone in Adhatoda vasica with photo diode array detection. Journal of liquid chromatography \& related technologies. 24(2):153-159.

31. Chetty KM (2006) Pharmaceutical studies and therapeutic uses of Plumbago zeylanica L. roots (Chitraka, Chitramulamu). Ethnobotanical Leaflets. 2006(1):33.

32. Bhattacharjee S (1998) Handbook of Medicinal Plants, Pointer Publications. India.293-294. 
33. Mittal V, JALWAL P, HOODA A, MOR J (2010) OF LEARNING AND MEMORY. International Journal of Pharma and Bio Sciences. 1:2.

34. Kirtikar K, Basu B (1975) Indian Medicinal Plants Jayyed Press: Delhi. Vol III.

35. Mallikadevi T, Paulsamy S (2010) Plumbago zeylanica L.-a potential plant for antimicrobial activity. Plant Archives. 10(2):547-550.

36. Kumar R, Kumar S, Patra A, Jayalakshmi S (2009) Hepatoprotective activity of aerial parts of Plumbago zeylanica linn against carbon tetrachloride-induced hepatotoxicity in rats. Int $\mathrm{J}$ Pharmacy Pharmaceut Sci. 1(1):171-175.

37. Williamson EM (2002) Major herbs of Ayurveda, Churchill Livingstone.

38. Chaudhari SS, Chaudhari G (2015) A review on plumbago zeylanica linn.-A divine medicinal plant. International Journal of Pharmaceutical Sciences Review and Research. 30(2):119-127.

39. Ganesan K, Gani SB (2013) Ethnomedical and Pharmacological Potentials of Plumbago zeylanica LA. American Journal of Phytomedicine and Clinical Therapeutics. 1(3):313-337.

40. Arunachalam KD, Velmurugan P, Raja RB (2010) Anti-inflammatory and cytotoxic effects of extract from Plumbago zeylanica. African journal of microbiology research. 4(12):1239-1245.

41. Li J, Li J, Cai G, Shen L, Lu F (2017) Proapoptotic and Growth-inhibitory Effects of Plumbagin on Human Gastric Cancer Cells Via Suppression of Signal Transducer and Activator of Transcription 3 and Protein Kinase B. Alternative Therapies in Health \& Medicine. 23(7).

42. Shweta S, Dubey S (2015) Antimicrobial activity of leaves extract of Plumbago zeylanica plant against known drugs. IJRSB. 3(6):1-6.

43. Honnegowda TM, Kumar P, Udupa EP, Sharan A, Singh R, Prasad HK, Rao P (2015) Effects of limited access dressing in chronic wounds: A biochemical and histological study. Indian journal of plastic surgery: official publication of the Association of Plastic Surgeons of India. 48(1):22.

44. Venkatadri B, Shanparvish E, Rameshkumar M, Arasu MV, Al-Dhabi NA, Ponnusamy VK, Agastian P (2020) Green synthesis of silver nanoparticles using aqueous rhizome extract of Zingiber officinale and Curcuma longa: In-vitro anti-cancer potential on human colon carcinoma HT-29 cells. Saudi Journal of Biological Sciences. 27(11):2980-2986.

45. Jyothi V, Fathima B (2013) Phytochemical evaluation \& pharmacological screening of wound healing \& antioxidant activity of Plumbago zeylanica. International Journal of Pharmacy and Technology. 5(3):5879-5891. 46. Falang KD, Uguru MO, Wannang NN, Azi H, Chiamaka N (2012) Anti-ulcer activity of Plumbago Zeylanica Linn. root extract. J Nat Prod Plant Resour. 2(5):563-567.

47. Sunil C, Duraipandiyan V, Agastian P, Ignacimuthu S (2012) Antidiabetic effect of plumbagin isolated from Plumbago zeylanica L. root and its effect on GLUT4 translocation in streptozotocin-induced diabetic rats. Food and chemical toxicology. 50(12):4356-4363.

48. Patil CD, Patil SV, Salunke BK, Salunkhe RB (2011) Bioefficacy of Plumbago zeylanica (Plumbaginaceae) and Cestrum nocturnum (Solanaceae) plant extracts against Aedes aegypti (Diptera: Culicide) and nontarget fish Poecilia reticulata. Parasitology research. 108(5):1253-1263.

49. Dang G, Parekar R, Kamat S, Scindia A, Rege N (2011) Antiinflammatory activity of Phyllanthus emblica, Plumbago zeylanica and Cyperus rotundus in acute models of inflammation. Phytotherapy Research. 25(6):904908.

50. Kodati DR, Burra S, Kumar G (2011) Evaluation of wound healing activity of methanolic root extract of Plumbago zeylanica L. in wistar albino rats. Asian Journal of Plant Science and Research. 1(2):26-34.

51. Zarmouh MM, Subramaniyam K, Viswanathan S, Kumar P (2010) Cause and effect of Plumbago zeylanica root extract on blood glucose and hepatic enzymes in experimental diabetic rats. African Journal of Microbiology Research. 4(24):2674-2677.

52. Vishnukanta, Rana A (2010) Evaluation of the Antifertility Activity of the Hydroalcoholic Extract of the Leaves of Plumbago Zeylanica L.(Plumbaginaceae) in Female Wistar Rats. Indian Journal of Pharmaceutical Education and Research. 44(1):49-55.

53. Sheeja E, Joshi S, Jain D (2010) Bioassay-guided isolation of anti-inflammatory and antinociceptive compound from Plumbago zeylanica leaf. Pharmaceutical biology. 48(4):381-387.

54. Nile SH, Khobragade C (2010) Antioxidant activity and flavonoid derivatives of Plumbago zeylanica. Journal of Natural Products. 3(16):130-133. 
55. Chauhan M (2014) A review on morphology, phytochemistry and pharmacological activities of medicinal herb Plumbago Zeylanica Linn. Journal of Pharmacognosy and Phytochemistry. 3(2).

56. Maniafu BM, Wilber L, Ndiege IO, Wanjala CC, Akenga TA (2009) Larvicidal activity of extracts from three Plumbago spp against Anopheles gambiae. Memórias do Instituto Oswaldo Cruz. 104(6):813-817.

57. Edwin S, Joshi SB, Jain DC (2009) Antifertility activity of leaves of Plumbago zeylanica Linn. in female albino rats. The European Journal of Contraception \& Reproductive Health Care. 14(3):233-239.

58. Checker R, Sharma D, Sandur SK, Khanam S, Poduval T (2009) Anti-inflammatory effects of plumbagin are mediated by inhibition of NF-kappaB activation in lymphocytes. International Immunopharmacology. 9(78):949-958.

59. Kotecha M, Rao K (2007) Clinical evaluation of haridra \& chitrak in the management of medoroga (obesity). Journal of ayurveda. 1:226-228.

60. Sandur SK, Ichikawa H, Sethi G, Ahn KS, Aggarwal BB (2006) Plumbagin (5-hydroxy-2-methyl-1, 4naphthoquinone) suppresses NF- $\kappa \mathrm{B}$ activation and NF- $\kappa \mathrm{B}$-regulated gene products through modulation of p65 and $\mathrm{I} \kappa \mathrm{B} \alpha$ kinase activation, leading to potentiation of apoptosis induced by cytokine and chemotherapeutic agents. Journal of Biological Chemistry. 281(25):17023-17033.

61. Dai Y, Hou L-F, Chan Y-P, Cheng L, But PP-H (2004) Inhibition of immediate allergic reactions by ethanol extract from Plumbago zeylanica stems. Biological and Pharmaceutical Bulletin. 27(3):429-432.

62. D'Souza R, Singh U, Aithal K, Udupa N (1998) Antifertility Activity Of Niosomal HPbCD-Plumbagin Complex. Indian journal of pharmaceutical sciences. 60(1):36.

63. Alpana R (1996) Effect of Plumbago zeylanica in hyperlipidaemic rabbits and its modification by vitamin E. Indian Journal of pharmacology. 28(3):161.

64. Rout JR, Kanungo S, Das R, Sahoo SL (2010) In vivo protein profiling and catalase activity of Plumbago zeylanica L. Nature and Science. 8(1):87-90.

65. Premakumari, P., Rathinam, K., \& Santhakumari, G. (1977). Antifertility activity of plumbagin. The Indian journal of medical research, 65(6), 829-838. 
www.ijppr.humanjournals.com

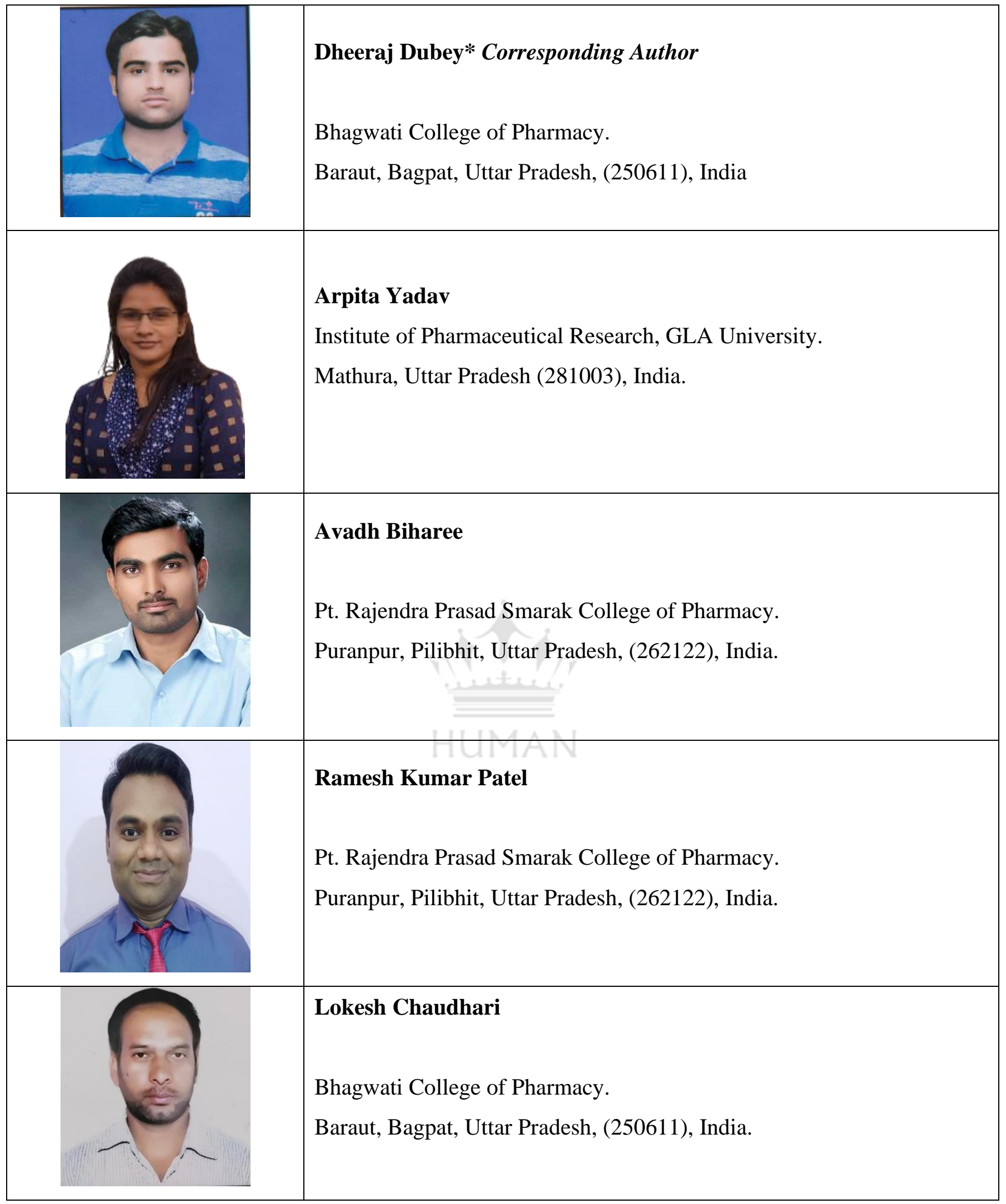

